УдК [658:351.863]-047.44

DOI: https://doi.org/10.32851/2708-0366/2021.10.4

Івончак I.O.

асистент кафредри економіки підприємства, Львівський національний університет імені Івана Франка

ORCID: https://orcid.org/0000-0002-1274-4344

Ivonchak Iryna

Ivan Franko National University of Lviv

\title{
АНАЛІЗ МЕТОДИЧНИХ ПІДХОДІВ ДО ОЦІНКИ РІВНЯ ЕКОНОМІЧНОЇ БЕЗПЕКИ ПІДПРИЄМНИЦТВА
}

\section{ANALYSIS OF METHODICAL APPROACHES TO ASSESSING THE LEVEL OF ECONOMIC SECURITY OF ENTREPRENEURSHIP}

\begin{abstract}
У статті проаналізовано методичні підходи до оцінювання рівня економічної безпеки підприємництва. Проведений аналіз сучасної наукової економічної літератури дав змогу виділити підходи науковців до методичного інструментарію для оцінки рівня економічної безпеки підприємництва. Разом із тим иче дало змогу виділити методичні підходи: ресурсно-функиіональний, індикаторний (пороговий), програмно-цільовий (комплексний), підхід на основі теорії економічних ризиків (аналіз імовірності банкрутства) та експертний. Здійснено поділ методичних підходів до оиінки економічної безпеки на традичійні та нестандартні групи. У межах розглянутих підходів визначено їхні переваги та недоліки, які доцільно враховувати під час оцінювання економічної безпеки підприємництва. Таким чином, проаналізовано теоретико-методичну основу здійснення оцінки рівня економічної безпеки підприємничтва. На основі наявних методичних підходів запропоновано заходи щуодо вдосконалення шляхів їх застосування.
\end{abstract}

Ключові слова: підприємництво, економічна безпека підприємницттва, оцінка економічної безпеки підприємництва, методичні підходи, оцінка.

В статье проанализированы методические подходы коценке уровня экономической безопасности предпринимательства. Проведенный анализ современной научной экономической литературы позволил выделить подходы ученых к методическому инструментарию для оценки уровня экономической безопасности предпринимательства. Вместе с тем это позволило выделить методические подходы: ресурсно-функичональный, индикаторный (пороговый), программно-иелевой (комплексный), подход на основе теории экономических рисков (анализ вероятности банкротства) и экспертный. Осуществлено разделение методических подходов к оиенке экономической безопасности на традиционные и нестандартныле группьл. В рамках рассмотренных подходов определень их преимущества и недостатки, которые ичелесообразно учитывать при оценке экономической безопасности предпринимательства. Таким образом, проанализирована теоретико-методическая основа проведения оценки уровня экономической безопасности предпринимательства. На основе существующих методических подходов предложены меры по совершенствованию путей их применения.

Ключевые слова: предпринимательство, экономическая безопасность предпринимательства, оченка экономической безопасности предпринимательства, методические подходы, оценка.

The study is devoted to the most common methodological approaches to assessing the level of economic security of entrepreneurship. The urgency of developing and implementing a system to maintain the appropriate level of economic security of business is due to current global trends in economic development, accompanied by an increase in the number of new risks and threats in a market economy. Assessing the economic security of entrepreneurship and the formation on its basis of appropriate management decisions are considered as one of the ways to ensure a level that is considered safe. That is why conducting an effective assessment of the level of economic security of entrepreneurship requires a comprehensive approach based on the use of a broad 
methodological framework. The analysis of modern scientific economic literature made it possible to identify the approaches of scientists involved in the development of methodological tools for assessing the level of economic security of entrepreneurship. At the same time, scientists carry out a methodical assessment of the level of economic security for each component and aggregate the results. The main methodological approaches include: resource-functional, indicator (threshold) approach, program-target (complex) approach, approach based on the theory of economic risks and expert approach (based on the use of expert assessments). Also in this research, a table of comparative characteristics of the main methodological approaches to assessing the economic security of entrepreneurship. Within the limits of the considered approaches their advantages and lacks which it is expedient to consider at an estimation of economic safety of business are defined. Traditional and non-standard approaches to assessing the level of economic security of entrepreneurship are considered, in particular, their types of methods are presented using a diagram-figure. Thus, as a result of the research, the theoretical and methodological basis for assessing the level of economic security of entrepreneurship was analyzed. Based on the existing methodological approaches, measures are proposed to improve the ways of their application, namely, scientific and practical recommendations, which in their content should intensify the formation of new approaches to assessing the level of economic security of entrepreneurship, based not only on retrospective analysis forecasting with the possibility of comparing them.

Key words: entrepreneurship, economic security of entrepreneurship, assessment of economic security of entrepreneurship, methodological approaches, assessment.

Постановка проблеми. Сучасні глобальні тенденції розвитку економіки, які супроводжуються зростанням кількості нових ризиків та загроз, зумовлюють необхідність дослідження проблематики забезпечення економічної безпеки підприємництва. Як наслідок, це вимагає комплексного підходу до використання методології оцінювання рівня економічної безпеки підприємництва. Проблема оцінювання економічної безпеки вважається одним із найменш досліджених складників, ураховуючи ії вагомість та практичне значення. Одержані результати проведеної оцінки вважаються базовою основою для реалізації управлінських рішень щодо забезпечення економічної безпеки. Зазначене актуалізує потребу поглибленого дослідження наявних підходів до оцінки рівня економічної безпеки підприємництва.

Аналіз останніх досліджень і публікацій. Проблемами розроблення теоретико-методичних основ щодо оцінки рівня економічної безпеки підприємництва займалися такі науковці, як Н. Бабіна, І. Бінько, О. Бородіна, В. Волошин, Т. Васильців, В. Геєць, Н. Гічова, Т. Гладченко, О. Груніна, С. Довбня, Ф. Євдокімов, В. Забродський, С. Ільяшенко, М. Кизим, Д. Ковальов, Г. Козаченко, О. Лященко, О. Мізіна, С. Міщенко, І. Плєтнікова, С. Покропивний, В. Пономарьов, В. Тамбовцев, Т. Хайлова, В. Халина, С. Шкарлет, Т. Шлемко та багато інших.

Проте наявність значної кількості наукових публікацій, присвячених даній тематиці, підтверджує не лише іiі актуальність, а й вимагає подальшого дослідження.

Формулювання цілей статті. Метою дослідження є аналіз та обгрунтування наявних науково-методичних підходів до оцінки рівня економічної безпеки підприємництва та визначення шляхів її вдосконалення.

Виклад основного матеріалу. Аналіз сучасної наукової літератури, присвяченої питанню оцінювання економічної безпеки підприємництва, підтверджує наявність значної кількості існуючих методичних підходів, які розроблені у цьому напрямі. Разом із тим варто зауважити, що існуючі підходи за своїми змістовими характеристиками часто ототожнюються або ж суттєво розмежовуються. Причиною такого різноманіття поглядів $є$ відсутність одностайної точки зору науковців щодо методичних підходів до оцінки рівня економічної безпеки підприємництва. Так, у науковому середовищі існує певний поділ у мірі сформованих підходів на традиційні або ж класичні та нестандартні (некласичні) групи. Так, на думку Т. Васильціва, класична група методичних підходів класифікується за підходами до оцінки та за методикою використання експертних оцінок. Відповідно, використання традиційних методичних підходів полягає в оцінюванні рівня економічної безпеки підприємства за допомогою аналізу та 
розрахунку показників рівня ефективності ресурсного потенціалу підприємства, його прибутковості, фінансової та конкурентної спроможності. Особливість застосування методичних підходів до оцінки рівня економічної безпеки підприємства шляхом проведення експертних оцінок поділяється на такі методи, де їх реалізація досягається виключно за експертними оцінками, та на такі, де оцінювання здійснюється переважно за формальними розрахунками, а експертні методи використовуються лише для окремих складників [2, с. 43].

До групи нестандартних (некласичних) відносяться такі методичні підходи оцінювання рівня економічної безпеки підприємництва, за яких:

1) оцінка проводиться за допомогою співвідношення величин брутто-інвестицій підприємництва до його ресурсного забезпечення;

2) реалізується на основі впливу ризиків;

3) здійснюється шляхом визначення ступеня захищеності майна (майнових ресурсів) підприємства;

4) розраховується рівень криміналізації економіки тощо (рис. 1).

Таким чином, аналізуючи наукові праці, присвячені методичним підходам до оцінки економічної безпеки підприємництва, доцільно розглянути ті, що вважаються найбільш відомими та мають практичне застосування з урахуванням їхніх переваг та недоліків (табл. 1).

Найбільш поширеним у практичному застосуванні методичним підходом уважається ресурсно-функціональний. Його сутність полягає у визначенні рівня економіч-

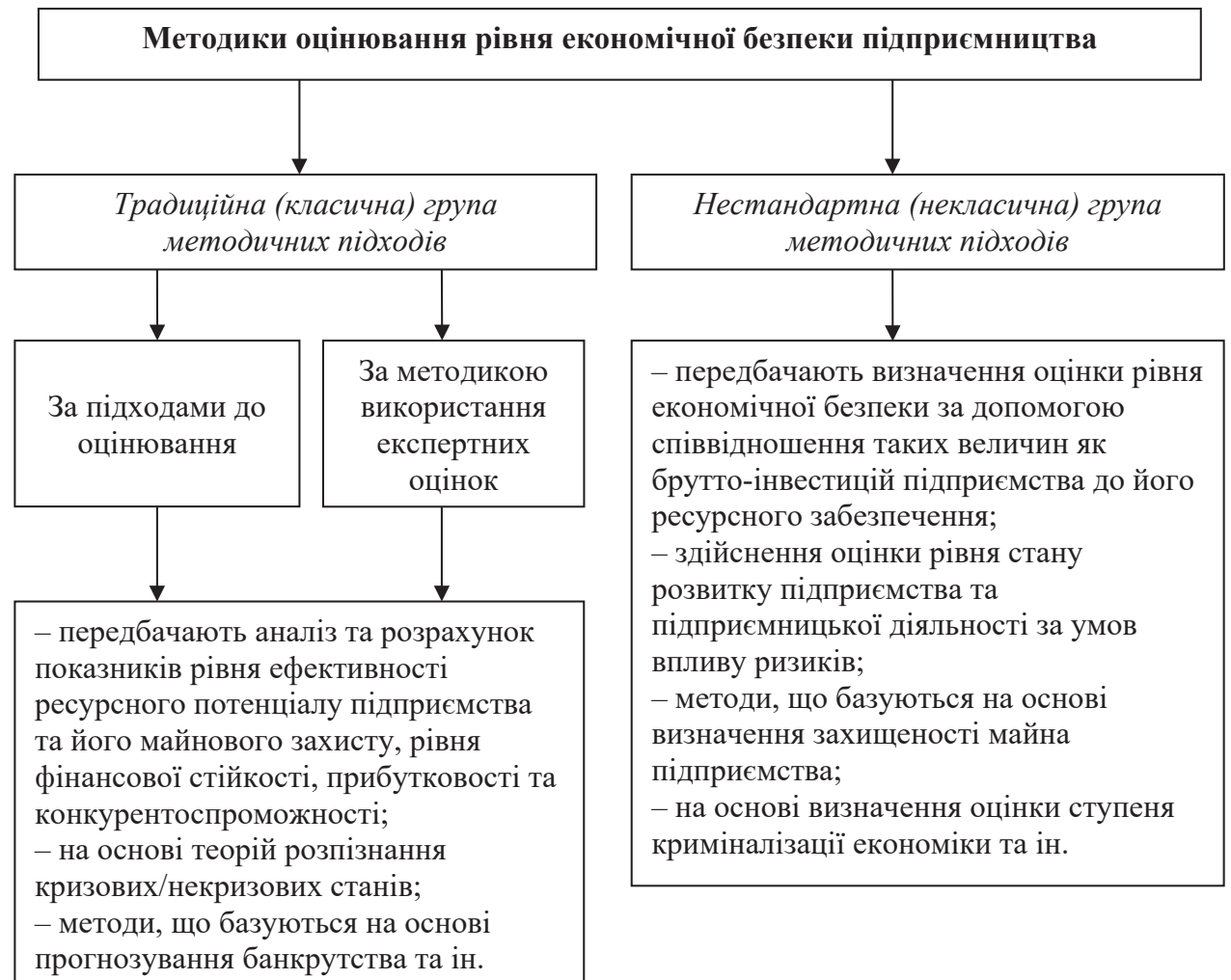

Рис. 1. Види методик щзодо оцінки рівня економічної безпеки підприємництва Джерело: складено автором на основі [2, с. 43] 
ної безпеки на основі оцінки ступеня ефективного розподілу ресурсного забезпечення підприємства за відповідними критеріями з урахуванням вагомості кожного функціонального складника економічної безпеки підприємства.

На думку С.Ф. Покропивного [9], проведення оцінки рівня економічної безпеки підприємства здійснюється за допомогою розрахунку загального критерію відповідно до зведення всіх окремих функціональних критеріїв, визначення котрих реалізується шляхом співвідношення можливої величини завданих збитків підприємству та суми затрачених коштів на здійснення запобіжних заходів щодо їх уникнення. Так, у своїх працях науковець серед типових функціональних складників економічної безпеки підприємства виокремлює такі, як фінансовий, техніко-технологічний, політико-правовий, інтелектуальний, силовий та екологічний.

Слід зазначати, що Д. Ковальов та І. Плетнікова для здійснення оцінки рівня економічної безпеки підприємства застосовують метод зведеного підсумку середніх значень локальних функцій залежності рівня економічної безпеки відповідно до чітко визначених показників діяльності підприємства, а саме фінансової стійкості, прибутковості, ліквідності тощо [9, с. 35-40].

Водночас С. Ільяшенко у своїх дослідженнях пропонує визначення рівня економічної безпеки підприємства здійснити за кожним окремими функціональним складником, використовуючи отримані дані для розрахунку інтегрального показника рівня економічної безпеки підприємства. Запропоноване методичне оцінювання передбачає проведення аналізу фінансової стійкості підприємства, що дає змогу визначити необхідний рівень обігових засобів для організації підприємницької діяльності [11, с. 16-22].

Т. Васильців до оцінки рівня економічної безпеки підприємництва додатково пропонує внести ще показники фінансової діяльності, що характеризують підприємницьку активність та рентабельність суб'єктів підприємництва. Перевагами запропонованого методичного підходу є його точність та глибина дослідження, комплексність у вивченні економічної безпеки підприємства на основі функціональних складників [2, с. 48].

Невирішеним питанням, що виступає своєрідним недоліком ресурсно-функціонального методичного підходу, є формування групи складників економічної безпеки підприємства, ураховуючи те, що вони не можуть бути уніфіковані для широкого використання на підприємствах через галузеві, організаційно-правові відмінності, що призводить до зниження об'єктивізму проведення оцінки.

Заслуговує на увагу індикаторний (пороговий) підхід до оцінки рівня економічної безпеки підприємництва. Його сутність полягає у співвідношенні порогових значень показників (індикаторів) із фактичними значеннями показників підприємства. Під пороговими значеннями індикаторів економічної безпеки слід розуміти граничні величини, неналежний рівень яких свідчить про наявність загроз економічній безпеці.

Представники індикаторного методичного підходу В.Т. Шлемко та І.Ф. Бінько використовують загальну оцінку стану фінансово-економічної безпеки підприємства, що визначається у співвідношенні граничних та фактичних значень відповідних індикаторів. Науковці пропонують для порівняння за основу вибрати одне з таких значень, як: показники тих підприємств, що мають спільний регіон розташування; показники підприємств-еталонів у галузі; показники зарубіжних підприємств-аналогів тощо [24, с. 68-70].

Для оцінювання рівня фінансово-економічної безпеки підприємства Л.В. Гнилицька рекомендує використовувати систему збалансованих індикаторів та згрупувати їх за напрямами стратегічного розвитку, зокрема фінансами, бізнес-процесами, клієнтами, кадровим потенціалом [6, с. 263-271]. Запропонована методика досліджує стан фінансової безпеки (фінансовий складник), основу якої становлять основні показники фінансово-господарської діяльності підприємства. Отже, сукупність використання таких індикаторів не відображає усіх фінансових аспектів функціонування підприємства.

Представники нетрадиційного методичного підходу до оцінки рівня економічної безпеки Г.В. Козаченко та В.П. Пономарьова [16, с. 104-106] пропонують використо- 


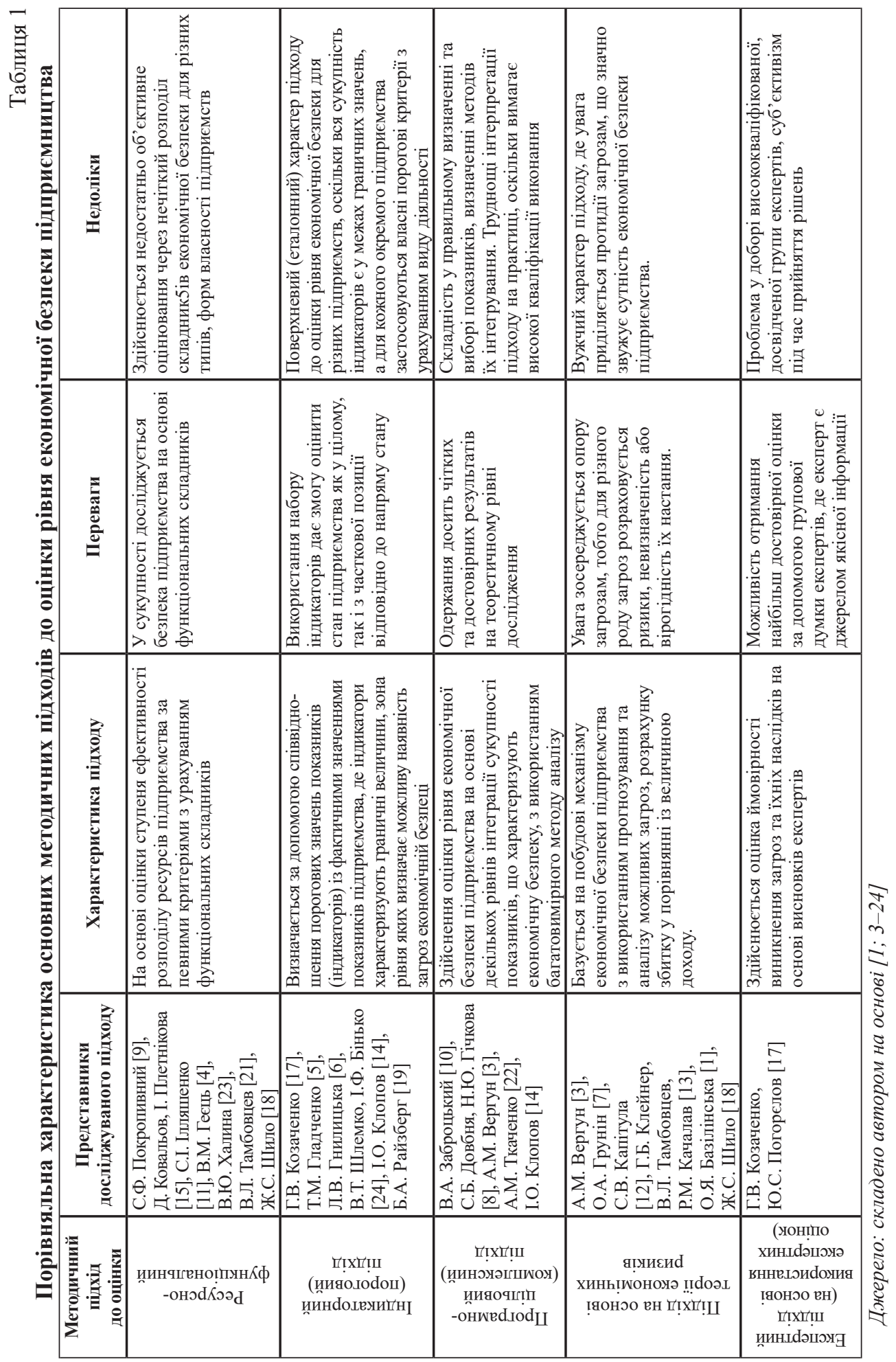


вувати для оцінювання стану економічної безпеки суб'єктів господарювання показник співвідношення обсягів брутто-інвестицій підприємства та інвестиційних ресурсів, що забезпечують умови економічної безпеки. При цьому забезпечення високого рівня економічної безпеки досягається за умови максимального наближення показника, що розраховується, до одиниці. Така методика передбачає розрахунок не лише кількісного, а й якісного показника, виокремлюючи рівень економічної безпеки, що визначається від мінімального до високого [16, с. 104-106]. Позитивною характеристикою індикаторного методичного підходу є використання набору індикаторів, що дає можливість проведення оцінки стану підприємства як у цілому, так і частково.

Ураховуючи зазначені особливості, рівень якості оцінювання економічної безпеки підприємства може бути низьким через суб'єктивізм визначення індикаторів та їхніх порогових значень у сучасних змінних ринкових умовах, які характеризуються значною мінливістю.

Заслуговує на увагу програмно-цільовий підхід, який базується на математичному методі аналізу та вирізняється складністю розрахунку. Особливістю розробленого підходу $€$ те, що визначення рівня економічної безпеки здійснюється на основі методів експертних оцінок за допомогою інтегрування показників, що визначають економічну безпеку.

Так, у межах зазначеного підходу науковець В. Заброцький пропонує оцінку рівня економічної безпеки підприємства проводити на основі інтеграції сукупності показників, що характеризують економічну безпеку. При цьому доцільно застосовувати декілька рівнів інтеграції показників із використанням кластерного та багатовимірного аналізу [10, с. $35-37]$.

У своїх дослідженнях С. Довбня та Н. Гічкова використовують комплексний підхід. Науковці пропонують застосувати метод «тривимірної діагностики рівня економічної безпеки підприємства», за яким здійснюється розрахунок середньозваженого значення рівня поточної, тактичної та стратегічної безпеки, що визначає загальний рівень економічної безпеки підприємства. Відповідно, визначення рівня економічної безпеки проводиться залежно від часового проміжку, у якому він оцінюється, та є зумовленим еволюційним характером кризових явищ [8, с. 88-97].

Особливою перевагою програмно-цільового підходу є можливість отримання чітких та достовірних результатів. Проте складність інтерпретації у практичному використанні, що вимагає високої кваліфікації під час виконання, характеризують недоліки зазначеного методу.

Важливим із позиції наукових досліджень $є$ підхід на основі теорії економічних ризиків, який грунтується на побудові механізму забезпечення економічної безпеки підприємства. У його основі лежить моделювання можливих загроз та їх аналіз. Насамперед це стосується аналізу ймовірності настання банкрутства, що базується на теоріях розпізнання кризових або ж некризових станів підприємства та грунтується на використанні методів прогнозування банкрутства.

Застосування дискримінантного аналізу вважається одним із найважливіших інструментів процесу ранньої діагностики та запобігання банкрутству. Відповідно, на основі використання математично-статистичних методів будують функцію та розраховують інтегральний показник із його критичним значенням, що дає можливість спрогнозувати настання банкрутства суб'єкта підприємництва майже з високою ймовірністю.

Найбільш поширеними методами діагностики ймовірності настання банкрутства у зарубіжній практиці є: модель Z-розрахунку Е. Альтмана, модель Г. Спрінгейта, модель Д. Фулмера, дискримінантна модель Р. Ліса, модель Р. Таффлера і Г. Тішоу, шкала Вівера, метод рейтингової оцінки Р.С. Сайфуліна і Г.Г. Кадикова та ін.

Особливою перевагою підходу на основі теорії економічних ризиків є можливість альтернативи у застосуванні методик проведення аналізу та оцінки рівня економічної безпеки підприємництва, де значна увага приділяється протидії загрозам, розрахункам невизначеності, ризикам або вірогідності їх настання. Однак для ефективного практич- 
ного застосування необхідні модифікація та адаптація наявних методик, що зумовлено необхідністю розроблення та використання науково обгрунтованих інтегрованих моделей, які б ефективно функціонували в умовах ринкової інтеграції вітчизняної економіки.

Недостатньо розповсюдженим методичним підходом до оцінки рівня економічної безпеки підприємництва вважається метод експертних оцінок. Зазначимо, що методи на основі висновків експертних груп використовують для здійснення прогнозування ймовірності настання загроз та їхніх наслідків для підприємницької діяльності.

Науковці Г.В. Козаченко та Ю.С. Погорєлов [17] для оцінювання економічної безпеки підприємництва пропонують використовувати метод експертних оцінок. Зазначена методика застосовується для аналізу об'єктів чи процесів, оцінювання яких не піддається формалізації та інтерпретації. Причиною використання експертних оцінок $є$, насамперед, відсутність повної чи достовірної інформації про стан об’єкта або результати його функціонування [20].

Використання експертного підходу дає можливість отримати найбільш достовірні дані, відповідно до яких експерт виступає джерелом надання якісної, достовірної інформації. Разом із тим цей метод характеризується і недоліками. Також варто відзначити і складність експертного оцінювання рівня економічної безпеки підприємництва в умовах швидкої зміни динаміки здійснення вітчизняної підприємницької діяльності.

Висновки. За результатами проведеного дослідження та аналізу наявних підходів до оцінки рівня економічної безпеки підприємництва, рейтингу популярності їх застосування можна констатувати, що кожен із розглянутих методичних підходів не можна назвати бездоганним. Відповідно, існування істотних переваг та суттєвих недоліків притаманно кожному з представлених підходів. Наявні методичні підходи потребують подальшого теоретичного дослідження та вдосконалення у практичному застосуванні. Із розвитком вітчизняної ринкової економіки доцільним $є$ формування нових підходів до оцінювання рівня економічної безпеки підприємництва, які б надали можливість отримувати більш достовірні результати щодо оцінювання рівня економічної безпеки та які б грунтувалися не лише на основі ретроспективного аналізу, а й ураховували перспективне прогнозування 3 можливістю проведення їх порівняння, що сприяло прийняттю більш вірних рішень.

Також доцільно під час дослідження нових методичних підходів для забезпечення комплексної, системної оцінки та проведення аналізу ураховувати галузеву специфіку підприємства та динаміку його діяльності; зосереджувати увагу на кожному функціональному складнику; визначати систему показників за кожним окремими складником, де буде висвітлено максимально чітко всі аспекти діяльності підприємства для здійснення точної оцінки економічної безпеки.

\section{Список використаних джерел:}

1. Базілінська О.Я. Фінансовий аналіз: теорія та практика : навчальний посібник. Київ : Центр навч. л-ри, 2009. 328 с.

2. Васильців Т.Г. Економічна безпека підприємництва України: стратегія та механізми зміцнення : монографія. Львів : Арал, 2008. С. 48.

3. Вергун А.М., Савченко М.М., Тарасенко I.О. Діагностика рівня фінансово-економічної безпеки підприємства. Інтернаука. 2015. № 2. С. 23-26. URL: http://nbuv.gov.ua/UJRN/ mnj_2015_2_6 (дата звернення: 10.10.2021).

4. Геєць В.М. Перешкоди економічному поступу та можливі шляхи їх подолання. Економічний часопис. 1996. № 11. С. 23-31.

5. Гладченко Т.М. Економічна безпека підприємницької діяльності. Актуальні проблеми міжнародних відносин. 2001. Вип. 26. С. 295-299.

6. Гнилицька Л.В. Використання концептуальних основ збалансованої системи економічних показників для оцінки стану та рівня економічної безпеки суб'єктів господарської діяльності. Фінанси, облік і аудит. 2011. № 18. С. 263-271.

7. Грунин О.А., Грунин С.О. Экономическая безопасность организации. Санкт-Петербург : Питер, 2002. 180 c. 
8. Довбня С.Б., Гічова Н.Ю. Діагностика рівня економічної безпеки підприємства. Фінанси України. 2008. № 4. С. 88-97.

9. Экономика предприятия : учебное пособие / под общ. ред. С.Ф. Покропивного. Киев : KHEУ, 2003. $608 \mathrm{c}$.

10. Забродский В., Капустин Н. Теоретические основы оценки экономической безопасности отрасли и фирмы. Бизнес Информ. 1999. № 15-16. С. 35-37.

11. Ильяшенко С.Н. Оценка составляющих экономической безопасности предприятия. Научные труды ДонНТУ. 2002. № 48. С. 16-22.

12. Капітула С.В. Оцінка та управління економічною безпекою підприємства (на прикладі гірничо-збагачувальних комбінатів України) : автореф. дис. ... канд. екон. наук : 08.00.04 ; Криворіз. техн. ун-т. Кривий Ріг, 2009. 20 с.

13. Клейнер Г.Б., Тамбовцев В.Л., Качалов Р.М. Предприятие в нестабильной экономической среде: риски, стратегии, безопасность. Москва : Экономика, 1997. 226 с.

14. Клопов І.О. Управління економічною безпекою промислового підприємства. Вісник Запорізького начіонального університету. 2011. № 1(9). C. 43-52. URL: http://web.znu.edu.ua/ herald/issues/2011/eco_2011_1/2011_1/043-52.pdf (дата звернення: 10.10.2021).

15. Ковальов Д., Плєтнікова І. Кількісна оцінка рівня економічної безпеки підприємства. Економіка Украӥни. 2001. № 4. С. 35-40.

16. Козаченко А.В., Пономарев В.П. Методические основы оценки уровня экономической безопасности предприятия. Региональные перспективы. 2010. № 2-3(9-10). С. 104-106.

17. Козаченко Г.В., Погорєлов Ю.С. Оцінювання економічної безпеки підприємства: аналіз основних підходів. Менеджмент безпеки держави, регіону, підприємства: проблеми і виклики сьогодення : колективна монографія / за заг. ред. З.Б. Живко, І.Г. Бабець. Львів : Ліга-Прес, 2015. С. 238-251.

18. Шило Ж.С. Конспект лекцій із дисципліни «Технологія діяльності аналітиків 3 питань фінансово-економічної безпеки» для студентів спеціальності 8.18010014 «Управління фінансово-економічною безпекою». Рівне : НУВГП, 2014. 49 с.

19. Райзберг Б.А. Государственное управление экономическими и социальными процесами : учебное пособие. Москва : Финансы, 2010. 412 с.

20. Рой О.М. Исследования социально-экономических и политических процессов : учебник для вузов. Санкт-Петербург : Питер, 2004. 364 с.

21. Тамбовцев В.Л. Экономическая безопасность хозяйственных систем: структура проблемы. Вестник Московского государственного университета. Серия «Экономика». 1995. № 3. С. 3-9.

22. Ткаченко А.М., Резніков О.Л. Оцінка рівня економічної безпеки підприємства. Вісник економічної науки України. 2010. № 1. С. 101-106.

23. Халіна В.Ю. Методичний підхід до оцінки рівня економічної безпеки підприємства. Вісник Чернівецького торговельно-економічного інституту. Економічні науки. 2014. Вип. 1. C. 173-181. URL: http://nbuv.gov.ua/UJRN/Vchtei_2014_1_24 (дата звернення: 10.10.2021).

24. Шлемко В.Т., Бінько І.Ф. Економічна безпека України: сутність і напрямки забезпечення : монографія. Київ : НІСД, 1997. С. 68-70.

\section{References:}

1. Bazilinska O.Ya. (2009) Finansovyy analiz: teoriya ta praktyka [Financial analysis: theory and practice]. Kyiv: Center for Educational Literature. (in Ukrainian)

2. Vasyltsiv T.G. (2008) Ekonomichna bezpeka pidpryiemnytstva Ukrainy: stratehiia ta mekhanizm zmitsnennia [Economic security of Ukrainian entrepreneurship: strategy and mechanism of strengthening]. Lviv: Aral. (in Ukrainian)

3. Vergun A.M., Savchenko M.M., Tarasenko I.O. (2015) Diahnostyka rivnya finansovo-ekonomichnoyi bezpeky pidpryyemstva [Diagnosis of the level of financial and economic security of the enterprise]. Mizhnarodnyy naukovyy zhurnal «Internauka» [International scientific journal "Internauka"] (electronic journal), no. 2, pp. 23-26. Available at: http://nbuv.gov.ua/UJRN/mnj_2015_2_6 (accessed 10 October 2021).

4. Geets V.M. (1996) Pereshkody ekonomichnomu postupu ta mozhlyvi shlyakhy yikh podolannya [Obstacles to economic progress and possible ways to overcome them]. Economic magazine, no. 11 , pp. 23-31.

5. Gladchenko T.M. (2001) Ekonomichna bezpeka pidpryyemnyts'koyi diyal'nosti [Economic security of business]. Current issues of international relations, vol. 26, pp. 295-299.

6. Gnylytska L.V. (2011) Vykorystannya kontseptual'nykh osnov zbalansovanoyi systemy ekonomichnykh pokaznykiv dlya otsinky stanu ta rivnya ekonomichnoyi bezpeky sub"yektiv hospodars'koyi 
diyal'nosti [Using the conceptual foundations of a balanced system of economic indicators to assess the status and level of economic security of economic entities]. Finance, accounting and auditing, no. 18 , pp. $263-271$.

7. Grunin O.A., Grunin S.O. (2002) Ekonomicheskaya bezopasnost organizatsii [Organization economic security]. St. Petersburg: SPb. (in Russian)

8. Dovbnya S.B., Gichova N.Y. (2008) Diahnostyka rivnya ekonomichnoyi bezpeky pidpryyemstva [Diagnosis of the level of economic security of the enterprise]. Finance of Ukraine, no. 4, pp. 88-97.

9. Pokropyvnyj S.F. (ed.) (2003) Ekonomika pidpryyemstva [Business Economics]. Kyiv: Kyiv National Economic University of Vadim Hetman. (in Ukrainian)

10. Zabrodsky V., Kapustin N. (1999) Teoretycheskye osnovy otsenky ekonomicheskoj bezopasnosti otryasly y firmy [The theoretical foundations for assessing economic security were shook off and firms]. Business-Inform, no. 15-16, pp. 35-37.

11. Ilyashenko S.N. (2002) Otsenka sostavlyayushchykh эkonomycheskoy bezopasnosty predpryyatyya [Assessment of the components of the economic security of the enterprise]. Sci. tr. DonNTU, no. 48 , pp. $16-22$.

12. Capitula S.V. (2009) Otsinka ta upravlinnya ekonomichnoyu bezpekoyu pidpryyemstva (na prykladi hirnycho-zbahachuval'nykh kombinativ Ukrayiny) [Assessment and management of economic security of the enterprise (on the example of mining and processing plants of Ukraine)] ( $\mathrm{PhD}$ Thesis), Kryvyi Rih: Kryvyi Rih Technical University.

13. Kleiner G.B., Tambovtsev V.L., Kachalov R.M. (1997) Predpryyatye v nestabyl'noy эkonomycheskoy srede: rysky, stratehyy, bezopasnost' [Enterprise in an unstable economic environment: risks, strategies, security]. Moscow: Economy. (in Russian)

14. Klopov I.O. (2011) Upravlinnya ekonomichnoyu bezpekoyu promyslovoho pidpryyemstva [Management of economic security of an industrial enterprise]. Visnyk Zaporiz'koho Natsional'noho universytetu [Bulletin of Zaporizhia National University] (electronic journal), no. 1(9), pp. 43-52. Available at: http://web.znu.edu.ua/herald/issues/2011/eco_2011_1/2011_1/043-52.pdf (accessed 10 October 2021).

15. Koval'ov D., Plyetnikova I. (2001) Kil'kisna otsinka rivnya ekonomichnoyi bezpeky pidpryyemstva [Quantitative assessment of the level of economic security of the enterprise]. Ukraine economy, no. 4, pp. 35-40.

16. Kozachenko A.V., Ponomarev V.P. (2010) Metodycheskye osnovu otsenky urovnya эkonomycheskoy bezopasnosty predpryyatyya [Methodical bases of an estimation of a level of economic safety of the enterprise]. Regional perspectives, no. 2-3(9-10), pp. 104-106.

17. Kozachenko H.V., Pohorelov Yu.S. (2015) Otsinyuvannya ekonomichnoyi bezpeky pidpryyemstva: analiz osnovnykh pidkhodiv [Assessment of economic security of the enterprise: analysis of basic approaches]. Menedzhment bezpeky derzhavy, rehionu, pidpryyemstva: problemy i vyklyky s'ohodennya [Security management of the state, region, enterprise: problems and challenges of today]. Lviv: Liha-Pres, pp. 238-251.

18. Shylo Zh.S. (2014) Upravlinnya finansovo-ekonomichnoyu bezpekoyu [Financial and economic security management]. Tenolohiya diyal'nosti analitykiv z pytan' finansovo-ekonomichnoyi bezpeky [Technology of activity of analysts on financial and economic security]. Rivne: NUWMES, pp. 49.

19. Rayzberh B.A. (2010) Hosudarstvennoe upravlenye ekonomycheskymy y sotsyal'numy protsesamy [Public administration of economic and social processes]. Moscow: Finance. (in Russian)

20. Roy O.M. (2004) Issledovanyya sotsyal'no-ekonomycheskykh y polytycheskykh protsessov [Studies of socio-economic and political processes]. St. Petersburg: SPb. (in Russian)

21. Tambovtsev V.L. (1995) Ekonomycheskaya bezopasnost' khozyaystvennkh system: struktura problemy [Economic security of economic systems: the structure of the problem]. Bulletin of Moscow State University. Series «Economics», no. 3, pp. 3-9.

22. Tkachenko A.M., Reznikov O.L. (2010) Otsinka rivnya ekonomichnoyi bezpeky pidpryyemstva [Assessment of the level of economic security of the enterprise]. Bulletin of Economic Science of Ukraine, no.1, pp. 101-106.

23. Khalina V.Yu. Metodychnyy pidkhid shchodo otsinky rivnya ekonomichnoyi bezpeky pidpryyemstva [Methodical approach to assessing the level of economic security of the enterprise]. Bulletin of the Chernivtsi Trade and Economic Institute. Economic sciences, vol. 1, pp. 173-181. Available at: http://web.znu.edu.ua/herald/issues/2011/eco_2011_1/2011_1/043-52.pdf (accessed 10 October 2021).

24. Shlemko V.T., Bin'ko I.F. (1997) Ekonomichna bezpeka Ukrayiny: sutnist' i napryamky zabez pechennya [Economic security of Ukraine: essence and directions of providing]. Kyiv: NISS. (in Ukrainian) 